\title{
PIERWSZA RODZINNA KATECHEZA DOMOWA W UJĘCIU ŚW. JANA CHRYZOSTOMA
}

Przyglądajazc się nłodemu Kościołowi, widzimy rzecz ciekawa. Nie miał on jeszcze własnycil szkół, dzieci chrześcijańskie uczyły się z pogańskimi, poganami byli nauczyciele. A jednak historia przekazała nam imiona młodzieży, która nie zachwiała się w wierze i, gdy zaszła potrzeba, otwarcie wyznawała Chrystusa, nierzadko płaczc za to męczeństwer. Iluż młodzieńców 1 dziewcząt, również dzieci, przelało krew, stałościa przekonań zadziwiajzc posiwiałych starców!

Gdzie przygotowali sie oni do tego bohaterstwa? Nietrudno na to odpowiedzieć. Siłe do wytrwania w wierze i w życiu chrześcijańskim otrzymali w rodzinie - od ojców i matek. Znamy ich imiona - to Leonidasy, Grzegorze i Nonny, Makryny i Emelie, Moniki

i Sylwie.

Rozumiał to ten, którego nazwano "doniosłym głosem Wschodu" późniejszy patriarcha Konstantynopola św.Jan Złotousty $/+407 /$. Stąd już jako prezbiter Kościoła antiocheńskiego zainteresował się on tym problemem $i$ swym przemyśleniom dał wyraz w rozprawie, skierowanej do wszystkich rodziców -tak do chrześcijańskich, jak i pogańskich. Jest niaz nieduża książeczka pt. "O próżnej chwale i wychowaniu dzieci" ${ }^{1}$. Nie sposób tu, na paru stronicach, podać cała jej zawartość. Ograniczymy się wi ̨̇c jedynie tylko do najbardziej charakterystycznych szczegółów.

W 90 krótkich rozdziałach podał Jan Chryzostom konkretne uwagi w odniesieniu do pierwszych lat dziecka. Zyciowa mądrościaz i świeżościa wychowawczej metody przemawiają one do nas i dzisiaj.

1 De inani gloria et puerorum educatione, ed. A.M.Malingrey/Jean Chrysostome, Sur la vaine gloire et l'éducation de enfants, Paris $1972 /$ SCh 188, tłum. W.Kania /Sw. Jan Chryzostom, Wybór pism, Warszawa 1974, 157-158; 0 wychowaniu dzieci/, PSP 13, 157-185. 
Już pierwszych słowach Doktor Kościoła zaznacza z naciskiem, że obowiązek wychowania potomstwa spoczywa przede wszystkim na rodzicach. Zwraca sie do nich stanowczo: "Nie przestane was upominać, prosić, zaklinać, abyście dobrze wychowywali swe dzieci. Jeśli kochasz dziecko, okaż to czynem" ${ }^{2}$. Gdzie indziej odpowiedzialnymi za to czyni zwłaszcza ojcọ́w, zaznaczając, że tylko ci otrzymać mogą miano ojca, którzy to zadanie należycie spełniają ${ }^{3}$. Nie pomija tu oczywiście matek. Sam mógł się przekonać kim są one dla młodych latorośli, gdy we wczesnym dzieciństwie straciz ojca Sekundusa $i$ cały ciężar wychowania spađłł na barki jego matki Antuzy ${ }^{4}$. Pokierowanie dzieckiem, wszczepienie w jego serce dobrych nawyków to przywilej matki, istórej nikt zastąpić nie zdoła.

Jan każe zająć się młodym człowiekiem od lat najwcześniejszych. W przeciwnym razie poniesie on wiele ran na duszy, które trzeba będzie długo leczyć. Niech służą tu przykładem zawodnicy olimpijscy, którzy od dzieciństra zaprawiaja się w ćwiczeniach cielesnych, by odnosić potem zwycięstwa i zbierać nagrody ${ }^{5}$. Wychowanie wywiera wpływ na całe życie dziecka:

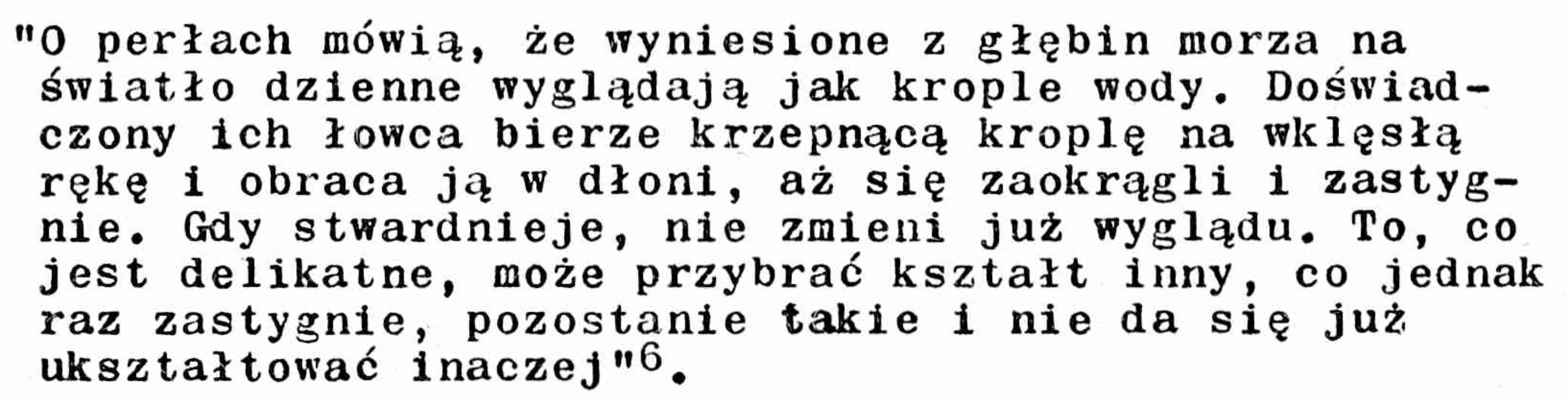

Większą uwage, niz na stworzenie dziecku materialnych warunków, należy zwrócić na wyrobienie jego charakteru:

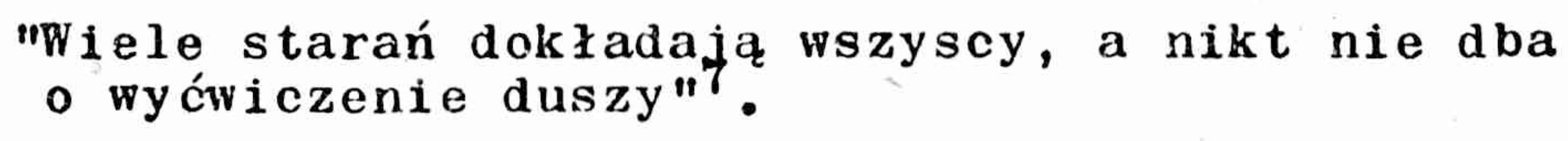

Jan gani rodziców, którzy starając sie tylko o majątek dla dziecka zaniedbuja jego uświęcenie:

\footnotetext{
2 De inani gloria 19, SCh 188, 102, PSP 13,164.

3 Por. Adversus oppugnatores vitae monasticae III 4, PG 47,356.

4 De sacerdotio I $2, \mathrm{SCh} 272,66$, POK $23,6$.

5 Por. Adversus oppugnatores vitae monasticae III 18, PG 47,379.

6 De inani gloria 21, SCh 188, 106, PSP 13, 164.

7 De inani gloria 18, SCh 188, 102, PSP 13,163.
} 


\begin{abstract}
"Niektórzy cały wysiłek obracają na to, aby swym dzieciom kupić pięknego konia, duży dom i majątek - ale - piękno ich dusz i poboźność ich serc nie starają sie wcale. Lezy w tym wielkie niebezpieczeństwo upadku ludzkości. Troszczymy się o majątek, a duszom pozwalamy ginąć. Jest to wielka głupota. Choćby syn miał wiele pieniędzy, jeśli nie będzie oszczędny, zmarnuje wszystko, natomiast gdy dusza jego została wychowana w cnotach, choćby mu przepadł majątek, zdobędzie wszystko, co jest potrzebne do zycia. Dlatego należ się starać nie tyle o złoto i srebro, lle o bogactwo pobożności i cnoty. Opanowanie 1 ucieczka od światowych uciech - oto prawdziwie bogaty posag" 8 .
\end{abstract}

Nie znaczy to jednak, że moźna obojętnie patrzeć na zewnętrzn̨̧ postawe dziecka, bo wiele ona mówi o jego wewnętrznym usposobieniu:

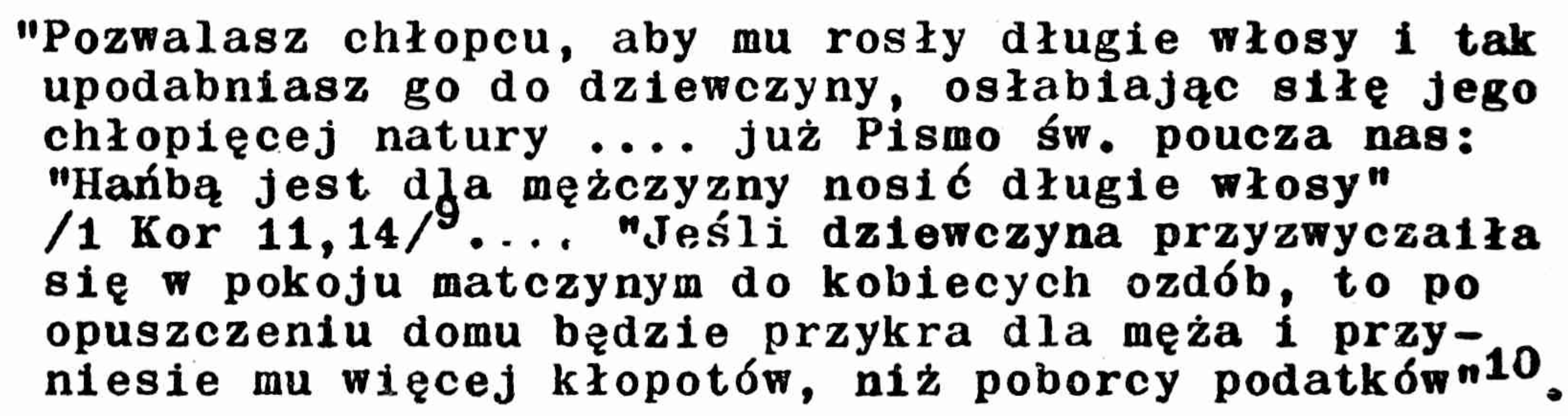
Rodzice powinnı więc od lat najmłodszych uczyć dzieci wieśc zycie w bojaźni Boźej: "Zepsucia świata nie można usunąć dlatego, że nikt nie zwraca uwagi na potomstwo, nikt mu nie mówi o dziewictwie, czystości, nie przecenianiu rozgłosu i bogactw, Bozych przykazaniach"11.

Fundamentem wychowania jest wpojenie młodemu prawdy, że "Bóg wszystko widzi - nawet to, co się dzieje w skrytości. Jeśi to wyrobisz u niego, nie będzie już potrzebował wychowawcyn. Te wiare w dobro wyraził równiez współczesny Janowi Augustyn w słowach: "Kochaj i czyń, co chcesz"12. Aby to osiazgnąc długaz drogaz musza zmierzać zgodnie wychowanek i wychowawca ${ }^{13}$.

Jak należy podchodzić do dziecka? Jan, znawca ludzkiej psy-

8 Por. In Matthaeum hom. 59,7, PG 58,583, tłum.J.Krystyniacki /Jana Chryzostoma wykład gwangelii św.Mateusza w 90 homiliach zawarty, t.1-3, Lwów 1903\% t.3, 18-19.

9 De inani gloria 16, SCh 188,98, PSP 13,163.

10 De inani gloria 17, SCh 188,100, PSP 13,163.

11 Tamże.

12 In I epistolam Joannis ad Pathos VII 8, SCh 75, 328, PSP 15,461.

13 Por. De inani gloria 40, SCh 188, 138, PSP 13,171. 
chiki, przedstawia to obrazowo. Wychowawca - pisze - podobny jest do króla, który ma zbudować miasto i osiedlić w nim obywateli ${ }^{14}$. Mastem - jest dusza dziecka, opasującym je murem - ciało, bramami, przez które wciskają się wrażenia, są zmysły, mieszkaniami - trzy wadze duszy: uczucie /thymos/, pożądanie /epithymia/ I rozum /logistikon/, obywatelami - uszlachetniające je cnoty: mestwo, wstrzemięzliwość i mądrość.

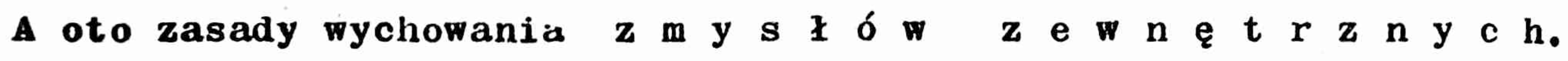
Przystapmy - pisze Jan - do pierwszej bramy, która najbardziej na to zasługuje - do bramy m o w y. Postarajmy sie o drzwi i zamek, nie o ten z drzewa lub z żelaza, lecz ze złota, to jest - Boża mowe "słodszą nad miód" /Ps 119,103/... "pożądliwszą nad złoto" /Ps 18,11/15. Uczmy dzieci wypowiadać tylko przyzwoite słowa, pilnujmy, aby sie nie dostały obelźwe mowy, nieprzystojne żarty. Niech przez tę bramę przechodzi sam Król i Jego świta wedle Psalmisty: "To jest brama Pańska, wejdą wią sprawiedliwi"/Ps $118,20 / 16$

Najblizej bramy mowy jest brama $s ı$ c $h$ u. Kto nie słucha złego, ten tez złego nie powie.

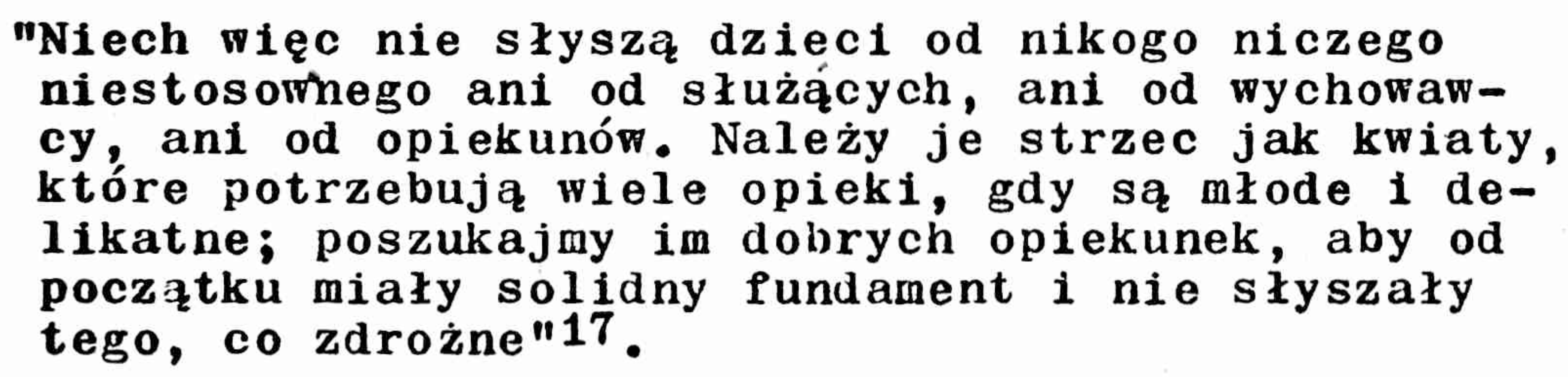

ådzice winni zawczasu podawać dzieciom budujące przykłady biblijne, gdyż żywe opowiadanie dodatnio wpływa na ich wyobraźnię. Przy tej okazji przytacza Chryzostom dwie wzorowe katechezy - o Kainie I Ablu oraz o Jakubie i Ezawie ${ }^{18}$. Wzruszające jest, jak wielki Doktor, który z ambony wstrząsał sumieniami wiernych, jako ka-

14 Por. De inani gloria 23, SCh 188, 110, PSP 13,165.

15 Por. De inani gloria 28, SCh 188, 116, PSP 13,166.

16 Tamże, SCh 188,116, PSP 13,166.

17 De inanii gloria 37 , SCh 188,128 , PSP 13, 168-169.

18 Por. De inani gloria 39-46, SCh 188, 130-144, PSP 13, 169-173. 
techeta potrafił z małymi być mały i przemawiać do nich jak ojciec. W całej literaturze patrystycznej nie znajdziemy lepszych katechez od tych wzorcowych wykładów biblijnych dla dzieci.

Mamy dalej bramę "piękniejszą od tamtych, choć trudną do strzezienia - patrzace na świat i chętnie widziane o c z y"19. Daje tu Jan surowe przepisy, m.in. dotyczace uczeszczania na teatralne widowiska. Mozumieny go, zdajac sobie sprawe, czyn one byky w jego czasach, kiedy to od dawna nie grano sztuk klasycznych, a ich miejsce zajęły pantomimy, przeplatane rubasznymi żartami i muzyka o motywach miłosnych zaczerpniętych z mitów. Nie przestaje jednak na zakazach, gdy zachęca:

"Pokaż dziecku piękne przedmioty, zwróc mu uwage
na niebo i gwiazdy, na ziemie i jej kwiaty - niech
tymi rzeczami zachwycają się jego oczy"20.

Jest jeszcze inna brama, rozciagająca się na całe ciało. Pozornie zamknięta, pozwala wszystkiemu dostać się do wnętrza, jakby była otwarta. Chodzi o zmysı d o t y k. I w tej dziedzinie Chryzostom poucza:

"Nie dopuścmy do wydelikacenia ciała przez szaty,
ani do poufałego zachowania sie dzieci wobec
drugich. Przyzwyczajmy chłopca do hartowania
ciała, znoszenia niewygód, sypiania na twardym
łożu, słowem do twardego trybu życia, aby wy-
chowac żołnierza. Trzymajmy w ten sposói zmysł
dotyku w ryzach" 21 .

Nie pomija Jan nawet zmysłu p o w o n i e n $i$, bowiem $i$ przez tę bramę wchodzi jego zdaniem wiele zepsucia:

"Nic tak nie odbiera duszy hartu i nie czyni jej ospała, jak upodobanie w przyjemnych zapachach. ... Tu budza się zdrożne zachcianki i pokusy do grzechu. Zanknij wi ̨̨c i tę bramę, bo jejzalaniem jest dostarczanie czystego powietrza, by nie chłeptać szkodliwych, choćby miłych wyziewów. Hoże ktoś się roześmieje, iż zwracamy uwagę na drobiazgi nakazując tutaj tak wielką ostrożność. Nie ma jednak drobiazgów, gdzie chodzi o moc, zlrowie i wychowanie ludzkiego rodzaju"22.

19 De inani gloria 55, SCh 188, 155, PSP 13, 175.

20 De inani gloria 59, SCh 188, 156, PSP 13,176.

21 De inani gloria $63, \operatorname{SCh} 188,162, \operatorname{PSP} 13,177$.

22 De inani gloria 54 , SCh $188,154$. 
Jak rozwijac w

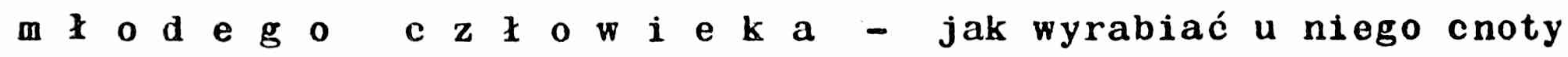
i wykorzeniać przeciwne im wady? $\mathrm{Na} m$ e $s t$ w o chłopca wskazują zgoda $i$ pokój, przeciwne im wady - to gniew i upór. Należy więc wdrażać młodego do cierpliwości w obliczu krzywdy, śpieszenia z pomoca pokrzywdzonym, uprzejmego obchodzenia sie ze słabszymi:

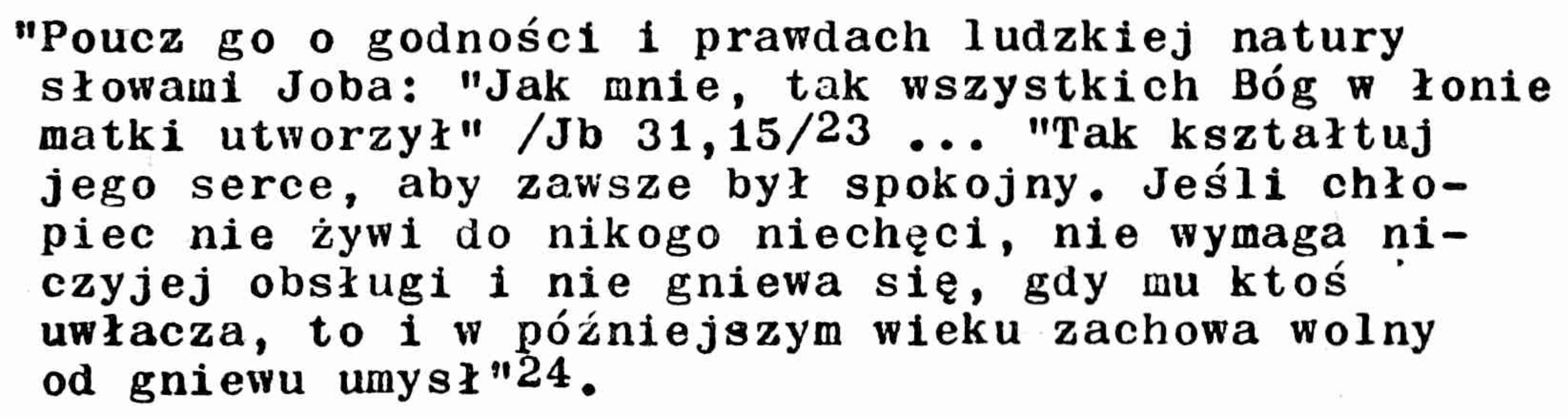

Druga ozdobą mitości jest w $\mathrm{s} t \quad r \quad z$ m $i$ e z 1 i w 0 ść. Dla jej nabycia trzeba nauczyć dzieci unikania okazji do złego, podejrzanych znajomości, nieprzyzwoitych widowisk. Wielka zaś pomocą będa wzniosłe wzory, przestrzeganie postu, prowadzenie do kościoła, pobożna i pokorna modlitwa. Jan wskazuje na piękne przykłady - Józefa egipskiego, Salomona, Jeremiasza, Daniela, którzy w młodości wiele czasu poświęcali modlitwie, bo "tylko zdziecinniały człowiek nie ma zrozumienia dla modlitwy"25. Najważniejszą jednak cnota młodego jest - zdaniem Chryzostomama $\mathrm{d} r$ o \& c :

\footnotetext{
"Potrzeba wiele pracy, aby wychować chłopca ku mądrości i wykluczyć z jego zycia wszelka głupotę. Jest to większa i od wszystkiego bardziej podziwu godna część Pilnzorii - wiedza o Bogu, o dobrach, które sa dla nas po drugiej stronie, - królestwie niebieskim, o piekle, bo "poczatkiem mądrości jest bojaźń Boźa" /Syr 1,7/26.
}

Tak pojęte mychowanie wymaga d u ż $\mathrm{g}$ o w y $s i \mathbf{i} u$ r 0 d z 1 c ó

"Jak malarze nad obrazem i rzeźbiarze nad posagiem
pracuja $z$ welkim trudem, tak 1 wy, ojcze i matko,

23 De inani gloria $72, \mathrm{SCh} 188,174, \mathrm{PSP} 13,180$.

24 De inani gloria $75, \operatorname{SCh} 188,176, \operatorname{PSP} 13,181$.

25 De inani gloria $80, \operatorname{SCh} 188,186, \operatorname{PSP} 13,182$.

26 De inani gloria $85, \operatorname{SCh} 188,192, \operatorname{PSP} 13,184$. 
musicie wnieść wiele staran wychowanie swych dzieci - tych godnych podziwu obrazów. Malarze ustawiaja tablice i dzień za dniem wodzą pędzlem wedle potrzeby, gorliwie tez pracuja rzeźbiarze, usurając to, co zbyteczne, uzupełniając braki Podobnie 1 wy rodzice, jak wykonawcy pieknych posagów, winniście podjąć wszelki trud, aby wychować swe dzieci na piękne obrazy Boga. Usuwajcie to, co niepotrzebne, uzupełniajcie braki, z dnia na dzień baczcie na skłonności swych dzieci - na dobre nawyki, by je rozwijać, na złe, by je wykorzeniacin27.

Na rodzicach zaniedbujących wychowanie dzieci ciaży w 1 e 1 a o d p o w 1 e d z $i$ a $l$ n o c. Zdadzą oni kiedyśs rachunek przea Najwyższym Sędzią, który powie:

"Uczyniłem was nauczycielami i przełoźonymi, opiekunami i kierownikami dzieci, w wasze rece przekazałem całą nad nimi władze, kazałem wam je umacniać i dosk onalić"28.

Choćby rodzice byli skądinąd dobrzy, to jednak w razie zantedbania dzieci, będa surowo karani. Odstraszajacym przykładem jest Heli, choć sam uczciwy, poniósł kare za to, ze nie karcił synów ${ }^{29}$. Niedbali rodzice są gorsi od zbójców, gdyż ich opieszałośc wiedzie dzieci do zguby. Jeśli natomiast dobrze wychowaja potomstwo, to ono wychowa swoje, a to znów następne:

\footnotetext{
"Jeśli dobrze wychowasz syna, a on podobnle swego, wtedy powstanie nieprzerwany łańcuch pięnego życia, zaczynający sie od ciebie, co tobie jako poczatkowi przyniesie nagrodę" 30 .
}

Jedna rzecz wymaga wyjaśnienia. Sw.Jan Złotousty nosi zaszczytny tytuł "Doktora Eucharystidn31. Może kogoś zdziwié, ze mówiąc w swych homiliach wiele o Najśw. Sakramencie i polecając wiernym częstą Komunię św. jako skuteczne źródło łaski do zwycięzenia namiętności 1 pokus, wsiązeczce o wychowaniu nie wspomnial

27 De inani gloria $22, \operatorname{SCh} 188,108, \operatorname{PSP} 13,164$.

28 Ecloga de liberorum educatione hom. 27, PG 63,766.

29 Por. Adversus oppugnatores vitae monasticae III 3, PG 47, 352.

30 Homilia in illud "Vidua eligatur" 10, PG 51,330.

31 Por. W.Kania, Eucharystia w pismach św.Jana Chryzostoma, HD 35/1966/ 120-123. 
o tym ani słowem. Jak to wytłumaczyć? Otóż trzeba pamiętać, że Chryzostom nie zwraca się tu wyłącznie do chrześcijan, ale ma na uwadze $i$ pogan. Wobec jednych $i$ drugich musial zachować obowiązujące jeszcze w tym czasie prawo tajemnicy/disciplina arcani/. W wielu też domach chrześcijańskich panował zwyczaj, że po narodzeniu dziecka wzywano kapłana, który na jego czole kreślił znak Krzyża św. i tak je przyjmował w poczet katechumenów, a chrzest odkładano na później. Doświadczył tego sam Chryzostom. Katechumeni mogli uczestniczyć we mszy św. do przygotowania darów ofiarnych, a potem musieli kościół opuszczać. Nic dziwnego, że zwracając się w swym dziełku równieź do katechumenów, o tym wielkim środiku łaski nie uczynił wzmianki 32 .

Przedstiawiona rozprawa "O próżnej chwale i wychowaniu dzieci" jest jedynym we wczesnym Kościele podręcznikiem wychowania, w którym Chryzostom przedstawił rodzicom ideał człowieka. Mocny duchem w wierze, nadziei 1 miłości winien on iść przez źycie ziemskie do życla wiecznego. Rozprawę tę ze względu na żywy, obrazowy i piękny język można w pełni nazwać "poematern wychowawczym".

$$
\text { Ks. Wojciech Kania - Tarnów }
$$

\section{PRIMA CATECHES IS DOMESTICA SECUNDUM JOANNEM CHRYS OSTOAUM /Argumentum/}

Primaevam Ecclesiam aspicientes rem sat mirabilem videmus. Nondum ei scholae proprie dictae erant, eius iuventus una cum pagana docebatur, magistri plerumque pagani erant. Attamen historia nobis luvenum nomina tradit, qui a fide numquam recesserunt, sed eam fortiter cum vitae discrimine ostenderunt, per multi pueri et puellae, etiam aetate parvuli, pro Christo sanguinem effuderunt. Vim ad fidem confitendam et christianam vitam peragendam in familia a parentibus acceperunt. Iamque bene hoc ille intellexit, quem posteri "claram Orientis vocem" necnon "christianum Demosthenem" vocaverunt. Felicitati omnium providens rem istam suam fecit eamque In libello "De inani gloria et puerorum educatione" expressit. Cuius opusculi argumentum verbis persequi id est, quod in articulo quaeritur.

32 S.Haidacher, Des hl. Johannes Chryzostomus Btchlein uber Hoffart und Kindererziehung aus seinen Schriften ubersetzt und herausgegeben, Freiburg Br. 1907, 28 . 